\title{
Vitamin D: Nutrient, Hormone, and Immunomodulator
}

\author{
Francesca Sassi, Cristina Tamone and Patrizia D'Amelio * \\ Department of Medical Science, Gerontology and Bone Metabolic Diseases, University of Turin, \\ 10126 Turin, Italy; francesca.sassi@unito.it (F.S.); cristinatamone78@gmail.com (C.T.) \\ * Correspondence: patrizia.damelio@unito.it; Tel.: +39-011-6335533
}

Received: 24 September 2018; Accepted: 31 October 2018; Published: 3 November 2018 updates

\begin{abstract}
The classical functions of vitamin D are to regulate calcium-phosphorus homeostasis and control bone metabolism. However, vitamin D deficiency has been reported in several chronic conditions associated with increased inflammation and deregulation of the immune system, such as diabetes, asthma, and rheumatoid arthritis. These observations, together with experimental studies, suggest a critical role for vitamin $\mathrm{D}$ in the modulation of immune function. This leads to the hypothesis of a disease-specific alteration of vitamin $\mathrm{D}$ metabolism and reinforces the role of vitamin $\mathrm{D}$ in maintaining a healthy immune system. Two key observations validate this important non-classical action of vitamin D: first, vitamin D receptor (VDR) is expressed by the majority of immune cells, including $\mathrm{B}$ and $\mathrm{T}$ lymphocytes, monocytes, macrophages, and dendritic cells; second, there is an active vitamin D metabolism by immune cells that is able to locally convert $25(\mathrm{OH}) \mathrm{D}_{3}$ into $1,25(\mathrm{OH})_{2} \mathrm{D}_{3}$, its active form. Vitamin $\mathrm{D}$ and VDR signaling together have a suppressive role on autoimmunity and an anti-inflammatory effect, promoting dendritic cell and regulatory T-cell differentiation and reducing $\mathrm{T}$ helper Th 17 cell response and inflammatory cytokines secretion. This review summarizes experimental data and clinical observations on the potential immunomodulating properties of vitamin D.
\end{abstract}

Keywords: vitamin D; immune system; gut microbiota; autoimmune diseases; T cells

\section{Introduction}

The role of vitamin D in the regulation of calcium-phosphate homeostasis and in the control of bone turnover is well known. Vitamin D status significantly affects skeletal health during growth and in adult age, its deficiency during growth leads to rickets [1], whereas during adult age it is responsible of osteomalacia and various degree of osteoporo-malacia [2]. Low vitamin D status increases bone turnover, decreases bone density, and is associated with increased fracture risk. In addition to the well-known effect on skeletal health in the last two decades evidence has been accumulated on the pleiotropic effect of vitamin $\mathrm{D}$ other than on bone health thanks to the findings that vitamin $\mathrm{D}$ receptor (VDR) and the vitamin D activating enzyme 1- $\alpha$-hydroxylase (CYP27B1) are expressed in several cells outside the bone and kidney, such as in the intestine, platelets, pancreas, and prostate [3]. Several cells involved in the immune function express VDR and CYP27B1, this observation suggests that the active form of vitamin $\mathrm{D}, 1,25(\mathrm{OH})_{2} \mathrm{D}_{3}$, is able to control the immune function at different levels. Previous reviews on the role of vitamin $\mathrm{D}$ in the regulation of immune system have been published in recent years $[4,5]$. Here we summarize the recent evidence sexploiting authors' expertise in both experimental and clinical fields. 


\section{Vitamin D Metabolism}

Vitamin D enters the body trough dietary intake (about $20 \%$ of vitamin $\mathrm{D}_{3}$ is assumed with diet) or is synthetized by the skin (80\%) from 7-dihydrocholesterol following UVB exposure. Vitamin $\mathrm{D}_{3}$ becomes biologically active after hydroxylation in the liver by the enzymes cytochrome P450 2R1 (CYP2R1) and cytochrome P450 27 (CYP27A1) becoming 25(OH) $\mathrm{D}_{3}$. The fully-active metabolite $1,25(\mathrm{OH})_{2} \mathrm{D}_{3}$ is hydroxylated in the kidney by the enzyme CYP27B1, parathormone (PTH), and the fibroblast growth factor 23 (FGF-23) control CYP27B1 synthesis and activity [6]. Synthesis of $1,25(\mathrm{OH})_{2} \mathrm{D}_{3}$ is strictly regulated in a renal negative feedback loop: high levels of $1,25(\mathrm{OH})_{2} \mathrm{D}_{3}$ and FGF-23 inhibit CYP27B1 and induce the cytochrome P45024A1(CYP24A1), which transforms $1,25(\mathrm{OH})_{2} \mathrm{D}_{3}$ into the inactive form $24(\mathrm{OH}) \mathrm{D}_{3}[7]$.

In addition to the kidney, CYP27B1 is expressed by other cell types, including immune cells. These cells produce $1,25(\mathrm{OH})_{2} \mathrm{D}_{3}$ that has autocrine and/or paracrine effects, the high level produced locally is thought to be responsible for immunomodulation. The regulation of CYP27B1 synthesis in immune cells is different than the signals regulating kidney production of $1,25(\mathrm{OH})_{2} \mathrm{D}_{3}$. Inflammatory signals, such as lipopolysaccharide (LPS) and cytokines, induce monocyte and macrophage production of CYP27B1 [8-10]. These differences in the regulation of $1,25(\mathrm{OH})_{2} \mathrm{D}_{3}$ production point to an autocrine/paracrine effect as immunomodulatory.

\section{Vitamin D Status}

Vitamin D status is defined by the blood measurement of its hydroxylated form $25(\mathrm{OH}) \mathrm{D}_{3}$, however, there is no common agreement on the threshold levels to identify desirable vitamin $\mathrm{D}$ level. Guidelines from different scientific societies and different countries established $50 \mathrm{nM} / \mathrm{L}$ or $75 \mathrm{nM} / \mathrm{L}$ to consider vitamin D sufficiency [11-13], however, it is generally accepted that $25(\mathrm{OH}) \mathrm{D}_{3}$ levels lower than $50 \mathrm{nM} / \mathrm{L}$ are associated with bone metabolism alteration, increased risk of falls, and myopathy in adults [14-18]. Experts in the field generally agree to maintain $25(\mathrm{OH}) \mathrm{D}_{3}$ between 20 and $125 \mathrm{nM} / \mathrm{L}$ in order to obtain the certain skeletal effects without toxic effects. Recent literature raises the suspicion that administration of a bolus of vitamin $\mathrm{D}_{3}$ higher than 50,000 UI may result in an increased risk of falls and fractures $[19,20]$; moreover, the mortality related to $25(\mathrm{OH}) \mathrm{D}_{3}$ is a "U shaped curve" and $25(\mathrm{OH}) \mathrm{D}_{3}$ levels higher than $150 \mathrm{nM} / \mathrm{L}$ are associated with increased mortality [21].

\section{Vitamin D and the Innate Immune System: Antimicrobial Activity}

The innate immune system is the first defense against infection, it is required to rapidly fight against invading pathogens. The innate immune system comprehends components both from the host and resident microbes (microbiota). The host defense comprises physical barriers to infection (as skin, mucous surfaces, mucus, and vascular endothelial cells), enzymes expressed by epithelial and phagocytic cells (as lysozyme), antimicrobial peptides and proteins (as defensins, cathelicidins, and others expressed by phagocytes), inflammatory humoral components (as complement and opsonins), and cell receptors that rapidly recognize pathogens (as toll-like receptors) and cellular components (as mast cells, dendritic cells, macrophages, neutrophils cells and natural killer). Interaction between microbiota a vitamin $\mathrm{D}$ will be analyzed in the following paragraph.

Vitamin D is a well-known regulator of innate immunity, the first data on this topic have been generated on the treatment of diseases caused by mycobacteria, such as tuberculosis and leprosy [22,23], however, the mechanisms responsible for these actions have been elucidated in more recent years. $1,25(\mathrm{OH})_{2} \mathrm{D}_{3}$ enhances the production of defensin $\beta 2$ and cathelicidin antimicrobial peptide (CAMP) by macrophage and monocyte keratinocytes increasing their antimicrobial activity [24-26]. Moreover, $1,25(\mathrm{OH})_{2} \mathrm{D}_{3}$ increases chemotaxis, autophagy, and phagolysosomal fusion of innate immune cells $[27,28]$. The exposition of human monocytes to pathogens, such as M. tuberculosis and others, up-regulates the expression of CYP27B1 and of VDR, thus enhancing both the cell ability to produce $1,25(\mathrm{OH})_{2} \mathrm{D}_{3}$ in the site of infection and to respond to this metabolite. However, macrophages are 
heterogeneous, with different functions [29]. Macrophages formed after interleukin (IL)-15 stimulus respond to vitamin D stimulus increasing their antimicrobial activity, whereas phagocytic macrophages obtained after stimulus with IL-10 are weakly influenced by vitamin D levels regardless oftheir high phagocytic activity [10,30].

$1,25(\mathrm{OH})_{2} \mathrm{D}_{3}$ up-regulates CAMP not only by monocytes/macrophages, but also in other cells participating in the innate immune system as first-barrier defenses, such as keratinocytes, epithelial, intestinal, lung and corneal cells, and placenta trophoblasts (see for a comprehensive review Wei and Christakos, 2015) [4].

Data in humans on infections other than mycobacterial have been generated on urinary and respiratory infections and on sepsis. A predisposition to urinary tract infection in children with low vitamin $\mathrm{D}$ levels due to the reduced production of CAMP and defensing $\beta 2$ has been suggested by association studies [31,32]. Additionally, in chronic obstructive pulmonary disease (COPD) patients' levels of CAMP and other antimicrobial peptides were associated with increased risk of acute exacerbations [33]. Consistent with this datum treatment with $1,25(\mathrm{OH})_{2} \mathrm{D}_{3}$ was effective in reducing respiratory infections in asthma patients thanks to increased CAMP expression and inflammatory cytokine modulation [34]. Data on the role of vitamin D status and vitamin D supplementation in sepsis are also available both in pediatric and in adult patients: in pediatric patients a clear role for $25(\mathrm{OH}) \mathrm{D}_{3}$ and CAMP was not demonstrated [35], whereas in adults lower levels of $25(\mathrm{OH}) \mathrm{D}_{3}$ were found in sepsis [36] and a high-dose of vitamin D3 increases circulating CAMP and reduces inflammatory cytokines as IL-6 and IL-1 $\beta$ [37].

More recently data on a possible role of vitamin D in increasing resistance to HIV infection have been published, in particular HIV-exposed seronegative individuals produced more CAMP in oral-mucosa and peripheral-blood, and have higher CYP24A1 mRNA in vaginal-mucosa; CYP24A1 is considered an indicator of high levels of $1,25(\mathrm{OH})_{2} \mathrm{D}_{3}$ [38]. Low serum vitamin $\mathrm{D}$ has been associated with HIV / AIDS progression and mortality [39].

$1,25(\mathrm{OH})_{2} \mathrm{D}_{3}$ is able to increase the production of other antimicrobial peptides, such as defensing $\beta 2-4$, this ability has been demonstrated both in vitro by monocytes stimulation $[40,41]$ and in vivo in pediatric patients' blood [32].

Vitamin D is able to modulate innate immune system, also increasing the phagocytic ability on immune cells $[42,43]$ and by reinforcing the physical barrier function of epithelial cells. In particular $1,25(\mathrm{OH})_{2} \mathrm{D}_{3}$ can enhance corneal [44] and intestinal [45] epithelial barrier function (Figure 1).

Taken together these data point to a role of vitamin $\mathrm{D}$ in defending the organism against pathogens suggesting that vitamin D sufficiency has to be granted in patients affected by acute or chronic infection. The ability of immune cells to hydroxylate $25(\mathrm{OH}) \mathrm{D}_{3}$ into its active form $1,25(\mathrm{OH})_{2} \mathrm{D}_{3}$ suggests administrating vitamin $\mathrm{D}_{3}$ rather than hydroxylated metabolites to patients affected by infections in order to allow the autocrine/paracrine function of $1,25(\mathrm{OH})_{2} \mathrm{D}_{3}$ without overcoming local hydroxylation and the feedback system.

\section{Vitamin D and Microbiota: Increasing Host Defenses}

The whole of the commensal, symbiotic, and pathogenic microorganisms living in different areas of the human body has defined microbiota. Microbiota and the host have several relationships, and the perfect balance between microbiota and the host is required for the development, maturation, and properfunction of the immune system [46]. Several papers suggest that vitamin D is one of the actors of the complex relationship between microbiota living in the gut (GM) and immune system modulation. Vitamin D is responsible for the barrier function of the intestinal epithelium and for the modulation of the bowel immune system, hence, low levels may be associated with greater gut permeability and, consequently, with GM-induced metabolic endotoxemia that induces a low-grade inflammation [47]. Moreover, vitamin D administration may influence GM composition, and in vitro data demonstrate that vitamin D enhances macrophages' ability to kill Escherichia coli. [48]. In animals with vitamin D depletion and the knockout of the VDR, the GM dysbiosis favors metabolic 
disorders [49]. Other studies in mice demonstrated that VDR reduces the response to infection of the intestinal epithelium [50].

Elegant studies in transgenic mice demonstrated that over-expression of VDR in the intestinal epithelium induces resistance to colitis [51,52] and decreases mucosal inflammation suppressing epithelial cell apoptosis, boosting tight junction function [51,53]. On the other hand VDR selective deletion in bowel favors a more severe form of colitis characterized by greater Th1 and Th17 mucosal infiltration and inflammatory cytokines production [54]. In humans, observational studies suggest that low levels of $25(\mathrm{OH}) \mathrm{D}_{3}$ are associated with increased risk of inflammatory bowel disease (IBD) [55-57] and that high levels of $25(\mathrm{OH}) \mathrm{D}_{3}$ in these patients protect against Clostridium difficile infection [58]. The experimental data on the role of VDR in developing IBD have been confirmed by the finding of a significant reduction of VDR expression (about 50\%) in the colon epithelium in patients affected by IBD with respect to healthy controls [51,53]. The reduction in VDR expression by IBD patients may explain the different effect on GM composition of high oral dosages of vitamin $\mathrm{D}_{3}$ demonstrated in a small cohort of patients affected by Crohn's disease with respect to healthy controls [59], however, human data on the effect of vitamin D supplementation on GM in IBD are still controversial, as other studies did not confirm these results [60,61]. In the study by Luthold and coll. [61] dietary intake of vitamin D and $25(\mathrm{OH}) \mathrm{D}_{3}$ were inversely correlated with Coprococcus and Bifidobacterium, however, thanks to their ability to produce butyrate these bacteria are commonly considered as anti-inflammatory. A possible explanation of these contradictory results may be the different effect of vitamin D on GM according to the different gastro-intestinal tracts considered [62]. Recently, a double-blind placebo-controlled study on patients affected by cystic fibrosis demonstrated that vitamin D insufficiency is associated with different microbiota not only in the gut, but also in the airways, and that the administration of $50,000 \mathrm{IU}$ of oral vitamin $\mathrm{D}_{3}$ weekly significantly affects microbiota composition [63]. Nevertheless, the evaluation of clinical outcomes of microbiota change is still open.

Several data point to an effect of vitamin D on microbiota. Conversely, some recent reports suggest that microbiota, per se, influences vitamin D metabolism mainly through FGF-23; germ-free (GF) mice have low vitamin D and high FGF-23, whereas their colonization with bacteria results in increased levels of tumor necrosis factor- $\alpha$ (TNF- $\alpha$ ) and a decrease in FGF-23 with normalization of vitamin D hydroxylated metabolites. Inhibition of FGF-23 in GF mice restores vitamin D metabolism without bacterial colonization of the gut [64] (Figure 1).

The role of GM as an active player in the regulation of bone metabolism in humans is being investigated more and more [46], and the role played by vitamin D is still under debate. Further studies to clarify their interplay are needed. 


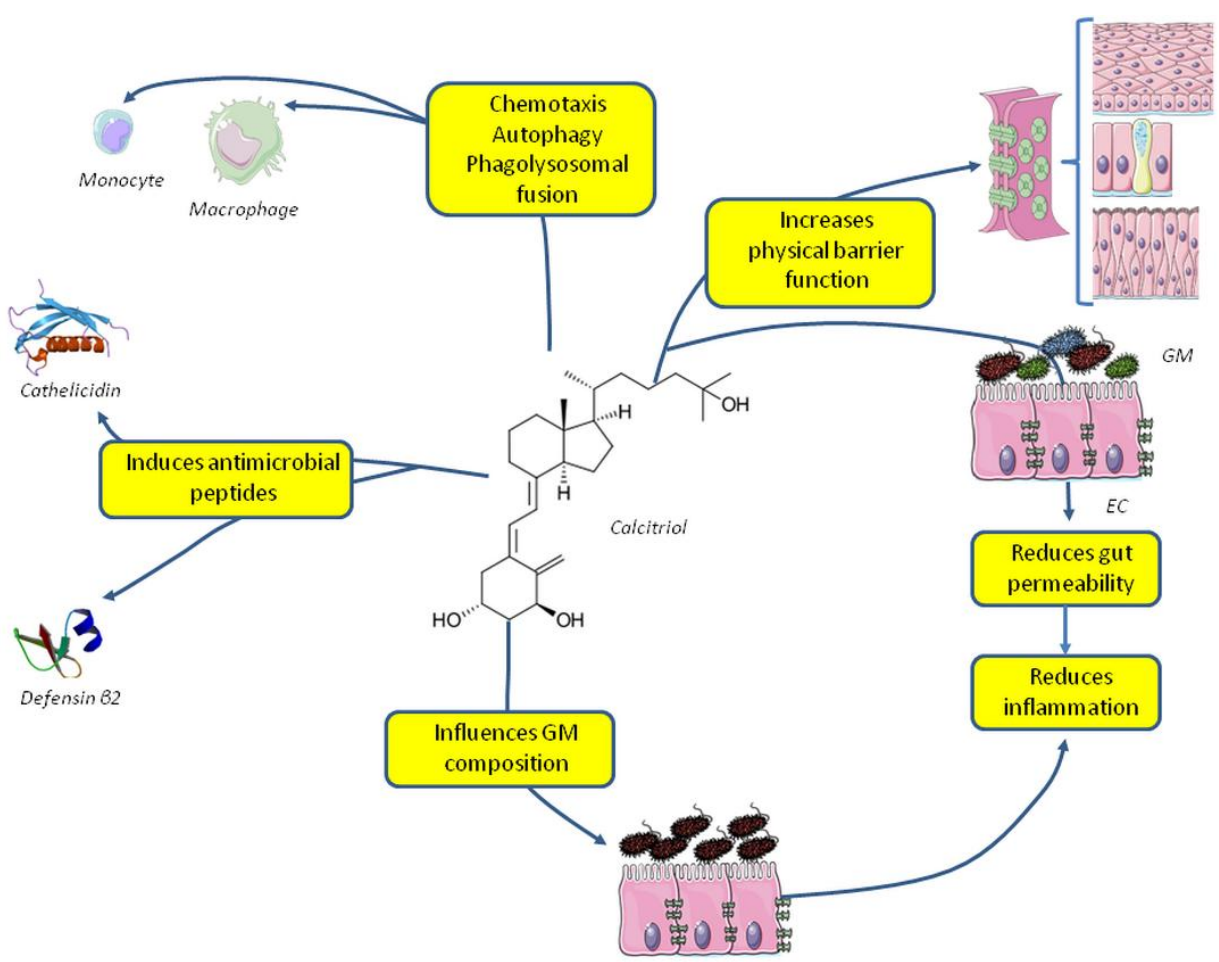

Figure 1. Effects of vitamin D on the innate immune system and gut microbiota. Abbreviations: EC, enteral cells; GM, gut microbiota.

\section{Vitamin $D$ and the Adaptive Immune System}

The adaptive immune system or acquired immune system is the second defense against infection. It is required to specifically fight against pathogens, is activated by exposure to pathogens, and unlike the innate immune system it is able to learn about the pathogen and enhance the immune response accordingly, thanks to an immunological memory. The adaptive immune system is composed of $\mathrm{T}$ and $\mathrm{B}$ cells and is also responsible for autoimmune reaction.

$25(\mathrm{OH}) \mathrm{D}_{3}$ suppresses adaptive immunity $[4,65]$. In experimental models it down-regulates the immune responses mediated by $\mathrm{T}$ helper (Th) 1 cells, thus inhibiting the production of pro-inflammatory cytokines, such as Interferon- $\gamma$ IFN- $\gamma$, IL-6, IL-2, and TNF- $\alpha[66,67]$. Although experimental studies in vitro and in animals have yielded encouraging results on the immunomodulatory effect of $1,25(\mathrm{OH})_{2} \mathrm{D}_{3}$, the same cannot be said about human studies, and few studies have confirmed the suppressive effect of vitamin D on Th1 cells and inflammatory cytokine production in different diseases and spinal tuberculosis [68], uremia [69], and autoimmune thyroiditis [70]; whereas others in IBD [71], dialysis [72], and rheumatoid arthritis [73] do not confirm these results. These discrepancies may be due to the different diseases considered and also to the different type of treatment administered, mainly $1,25(\mathrm{OH})_{2} \mathrm{D}_{3}$ in vitro and in animals and vitamin $\mathrm{D}_{3}$ in vivo in humans. Moreover, when considering administration of vitamin D3 different doses were used in different studies. Therefore, it is almost impossible to compare the results.

It has been suggested that $1,25(\mathrm{OH})_{2} \mathrm{D}_{3}$ acts as an immunomodulatory not only by suppressing Th1 cells activation, but also modulating Th2 cells, T regulatory (Tregs) cells activity, and Th17 cells.

The majority of the in vitro studies assessing the effect of vitamin D on Th2 suggests that $1,25(\mathrm{OH})_{2} \mathrm{D}_{3}$ upregulates Th2 cells activity [74-76]. Amongst immunomodulatory effects of vitamin D its ability to suppress Th17 and increase Treg cells has been recently demonstrated [77-79]. Th17 cells produce IL-17 and have been implicated in the pathogenesis ofseveral autoimmune diseases, some experimental studies suggest that $1,25(\mathrm{OH})_{2} \mathrm{D}_{3}$ suppresses Th17 formation and activity $[67,80-83]$ by blocking Nuclear Factor of Activated T-cells (NFAT) and Runt-related Transcription Factor 1 
(RUNx1) binding to the IL-17 promoter and inducing Forkhead box P3 (FOXP3) [81], and by inhibiting RAR-related Orphan Receptor Gamma2 (ROR $\gamma \mathrm{t}$ ) which is the transcription factor of IL-17 [84].

More recently our lab showed no effect of the administration of a high bolus of vitamin $\mathrm{D}_{3}$ (300,000 UI) in the modulation of Th subset in patients affected by early rheumatoid arthritis [73], as well as a study on hemodialysis patients [72].

It has also been suggested that the administration of oral vitamin $\mathrm{D}_{3}$ increases Tregs function in patients with type 1 diabetes mellitus [85], however, in other diseases, such as early rheumatoid arthritis, this effect was not confirmed [73].

The overall effect of vitamin D on Th cells differentiation may be mediated by its effect on dendritic cells, these cells are antigen-presenting cells (APCs), responsible for T cell differentiation into an effector cell with pro- or anti-inflammatory properties, thus, modulation of APCs is crucial in initiating and maintaining adaptive immune response and self-tolerance [86]. In vitro differentiation of dendritic cells in the presence of $1,25(\mathrm{OH})_{2} \mathrm{D}_{3}$ induces a "tolerogenic state" characterized by low levels of inflammatory cytokines, such as IL-12 and TNF- $\alpha$, with increased levels of the anti-inflammatory IL-10, these cells induce the differentiation of Treg cells and induce apoptosis in the autoreactive T cells [87-90] (Figure 2).

Taken together these data are not sufficient to prove a real role for vitamin $\mathrm{D}$ in the modulation of adaptive immune system in humans, thus, the therapeutic use of vitamin D and its metabolites in patients aiming to ameliorate the adaptive immune system is not sustained by sufficient data.

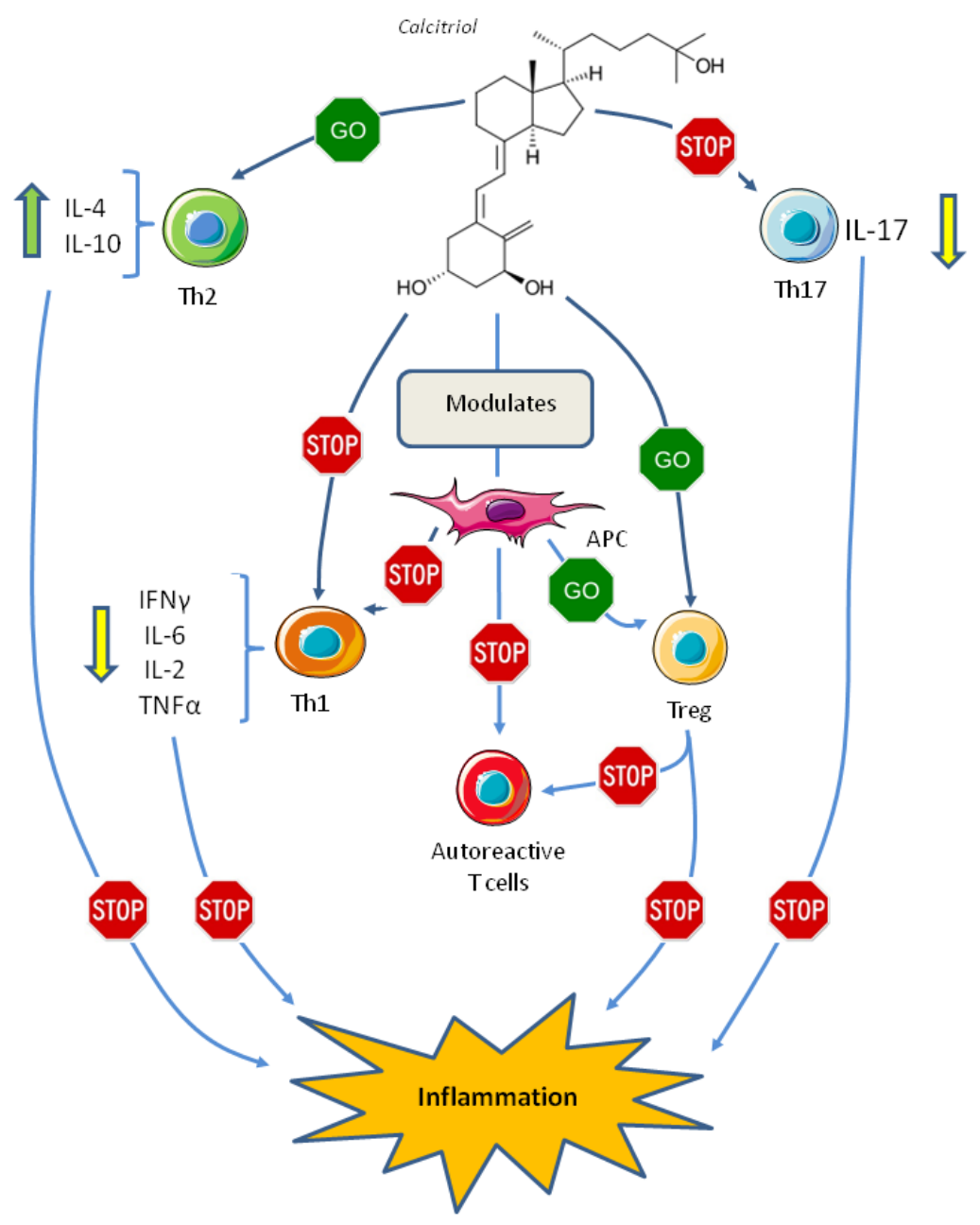

Figure 2. Effect of vitamin D on the adaptive immune system. Abbreviations: APC, antigen presenting cell; IFN, interferon; IL, interleukin; Th1, T helper 1 cell; Th2, T helper 2 cell; Th17, T helper 17 cell; TNF, tumor necrosis factor; Treg, T regulatory cell. 


\section{Vitamin D and Autoimmune Diseases}

Thanks to the evidences of immunomodulatory effect of vitamin $D$ the role of vitamin D deficiency and supplementation in autoimmune diseases has long been studied. Animal studies showed an important role of $1,25(\mathrm{OH})_{2} \mathrm{D}_{3}$ supplementation in the control of autoimmune diseases, such as experimental autoimmune encephalomyelitis (EAE) and collagen-induced arthritis (CIA). In these two conditions $1,25(\mathrm{OH})_{2} \mathrm{D}_{3}$ prevents the initiation and reduces the disease progression [91-93]. Similarly, different mouse models of enterocolitis display a more severe phenotype during vitamin $\mathrm{D}$ deficiency and reduced inflammation after administration of $1,25(\mathrm{OH})_{2} \mathrm{D}_{3}$ (see for a review Alhassan et al., 2017) [94]. Despite solid experimental evidence human studies are less convincing: some epidemiological data link increasing latitude and consequent decrease sunlight exposure with higher prevalence of multiple sclerosis [95-97], type I diabetes [98-100], and IBD [101]. It is clear that such differences may be due to genetic and lifestyle factors other than $25(\mathrm{OH}) \mathrm{D}_{3}$ levels. Other epidemiological data reinforcing the hypothesis of a link between sun exposure, vitamin $\mathrm{D}$ synthesis, and the risk of developing multiple sclerosis stem from the observation that subjects born in months associated with lower $25(\mathrm{OH}) \mathrm{D}_{3}$ level in the northern hemisphere (April) are at higher risk of developing the disease, whereas patients born in October (higher vitamin D levels) are at lower risk [102].

Some studies correlated vitamin D dietary intake and the prevalence of autoimmune diseases as rheumatoid arthritis [103] and type 1 diabetes mellitus [104,105], however, the correct evaluation of vitamin $\mathrm{D}$ intake is challenging as it is based on patient recall. To bypass the challenging measurement of vitamin $\mathrm{D}$ intake and sun exposure, levels of $25(\mathrm{OH}) \mathrm{D}_{3}$ in the serum can be useful, and, indeed, low levels of $25(\mathrm{OH}) \mathrm{D}_{3}$ in the serum of patients affected by autoimmune diseases with respect to healthy controls have been found [106-112]. Nevertheless, these studies demonstrated a correlation and not a causal relationship.

Intervention studies with different doses of vitamin $\mathrm{D}_{3}$ in autoimmune diseases lead to different outcomes, recently we demonstrated that a bolus of vitamin $\mathrm{D}_{3}(300,000 \mathrm{UI})$ in patients affected by early rheumatoid arthritis is effective in ameliorating general health, however, we found no effect on disease activity nor on inflammatory markers and $T$ cells subset [73]. In patients affected by type 1 diabetes clinical intervention studies with vitamin $\mathrm{D}_{3}$ or hydroxylated analogs have been disappointing, as no clinical study has demonstratedan effect of vitamin $\mathrm{D}$ in ameliorating glucose metabolism and insulin secretion $[113,114]$, however, in a small prospective trial in children with type 1 diabetes autoantibodies $1,25(\mathrm{OH})_{2} \mathrm{D}_{3}$ administration decreased the serum glutamic acid decarboxylase 65 (GAD65) autoantibody, pointing to some immunomodulation of $1,25(\mathrm{OH})_{2} \mathrm{D}_{3}$ [115].

In addition to autoimmune diseases vitamin $\mathrm{D}$ has also been implicated in the control of other inflammatory conditions, such as cardiovascular diseases: in animal models vitamin $\mathrm{D}_{3}$ administration reduces macrophage production of pro-inflammatory cytokines, and decreases atherosclerosis and inflammation in the epicardial adipose tissue $[116,117]$. In humans an association between low $25(\mathrm{OH}) \mathrm{D}_{3}$ level and increased activation of inflammatory pathway in epicardial adipose tissuein patients affected by coronary artery disease has been described [118]. Vitamin D deficiency has been linked to cardiovascular disease not only by the modulation of inflammatory pathways, but also through the modulation of endothelial function, the effect on arterial stiffness, and a possible beneficial role on atherosclerotic plaque formation. However, this topic is beyond the scope of this review. For further insight in the role of vitamin $\mathrm{D}$ in the pathogenesis of cardiovascular disease see the review by Apostolakis and coll. [119].

\section{Conclusions}

In summary, several studies point to an important role of vitamin $\mathrm{D}$ as an immunomodulator, and strong data demonstrate a role for $1,25(\mathrm{OH})_{2} \mathrm{D}_{3}$ in increasing the ability of the innate immune system to fight against pathogens, whereas data on the effect of $1,25(\mathrm{OH})_{2} \mathrm{D}_{3}$ in the modulation of acquired immune system are more controversial. There is no general consensus on the desired level of 
$25(\mathrm{OH}) \mathrm{D}_{3}$ to achieve immunomodulatory effects, thus, there is no current indication for vitamin $\mathrm{D}_{3}$ supplementation in patients with infections and/or autoimmune diseases. Further studies are needed to clarify the role of vitamin D as immunomodulator in humans.

Author Contributions: All three authors participated in the bibliographic search, discussion and writing of the manuscript. The manuscript was finalized by P.D.

Funding: This research received no external funding

Conflicts of Interest: The authors declare that they have no conflict of interest.

\section{References}

1. Antonucci, R.; Locci, C.; Clemente, M.G.; Chicconi, E.; Antonucci, L. Vitamin D deficiency in childhood: Old lessons and current challenges. J. Pediatr. Endocrinol. Metab. 2018, 31, 247-260. [CrossRef] [PubMed]

2. Uday, S.; Högler, W. Prevention of rickets and osteomalacia in the UK: Political action overdue. Arch. Dis. Child. 2018, 103, 901-906. [CrossRef] [PubMed]

3. D'Amelio, P.; Cristofaro, M.A.; De Vivo, E.; Ravazzoli, M.; Grosso, E.; Di Bella, S.; Aime, M.; Cotto, N.; Silvagno, F.; Isaia, G.; et al. Platelet vitamin D receptor is reduced in osteoporotic patients. Panminerva Med. 2012, 54, 225-231. [PubMed]

4. Wei, R.; Christakos, S. Mechanisms Underlying the regulation of innate and adaptive immunity by vitamin D. Nutrients 2015, 7, 8251-8260. [CrossRef] [PubMed]

5. Altieri, B.; Muscogiuri, G.; Barrea, L.; Mathieu, C.; Vallone, C.V.; Mascitelli, L.; Bizzaro, G.; Altieri, V.M.; Tirabassi, G.; Balercia, G.; et al. Does vitamin D play a role in autoimmune endocrine? A proof of concept. Rev. Endocr. Metab. Disord. 2013, 18, 335-346. [CrossRef] [PubMed]

6. Borel, P.; Caillaud, D.; Cano, N.J. Vitamin D bioavailability: State of the art. Crit. Rev. Food Sci. Nutr. 2015, 55, 1193-1205. [CrossRef] [PubMed]

7. Anderson, P.H. Vitamin D Activity and Metabolism in Bone. Curr. Osteoporos. Rep. 2017, 15, 443-449. [CrossRef] [PubMed]

8. Liu, P.T.; Stenger, S.; Li, H.; Wenzel, L.; Tan, B.H.; Krutzik, S.R.; Ochoa, M.T.; Schauber, J.; Wu, K.; Meinken, C.; et al. Toll-like receptor triggering of a vitamin D-mediated human antimicrobial response. Science 2006, 311, 1770-1773. [CrossRef] [PubMed]

9. Stoffels, K.; Overbergh, L.; Giulietti, A.; Verlinden, L.; Bouillon, R.; Mathieu, C. Immune regulation of 25-hydroxyvitamin-D $\mathrm{D}_{3}-1$ alpha-hydroxylase in human monocytes. J. Bone Miner. Res. 2006, 21, 37-47. [CrossRef] [PubMed]

10. Krutzik, S.R.; Hewison, M.; Liu, P.T.; Robles, J.A.; Stenger, S.; Adams, J.S.; Modlin, R.L. IL-15 links TLR2/1-induced macrophage differentiation to the vitamin D-dependent antimicrobial pathway. J. Immunol. 2008, 181, 7115-7120. [CrossRef] [PubMed]

11. Ross, A.C.; Manson, J.E.; Abrams, S.A.; Aloia, J.F.; Brannon, P.M.; Clinton, S.K.; Durazo-Arvizu, R.A.; Gallagher, J.C.; Gallo, R.L.; Jones, G.; et al. The 2011 report on dietary reference intakes for calcium and vitamin D from the Institute of Medicine: What clinicians need to know. J. Clin. Endocrinol. Metab. 2011, 96, 53-58. [CrossRef] [PubMed]

12. Holick, M.F.; Binkley, N.C.; Bischoff-Ferrari, H.A.; Gordon, C.M.; Hanley, D.A.; Heaney, R.P.; Murad, M.H.; Weaver, C.M. Endocrine Society Evaluation, treatment, and prevention of vitamin D deficiency: An Endocrine Society clinical practice guideline. J. Clin. Endocrinol. Metab. 2011, 96, 1911-1930. [CrossRef] [PubMed]

13. Cesareo, R.; Attanasio, R.; Caputo, M.; Castello, R.; Chiodini, I.; Falchetti, A.; Guglielmi, R.; Papini, E.; Santonati, A.; Scillitani, A.; et al. Italian Association of Clinical Endocrinologists (AME) and Italian chapter of the American Association of Clinical Endocrinologists (AACE) position statement: Clinical management of vitamin D deficiency in adults. Nutrients 2018, 10, 546. [CrossRef] [PubMed]

14. Valcour, A.; Blocki, F.; Hawkins, D.M.; Rao, S.D. Effects of age and serum 25-OH-vitamin D on serum parathyroid hormone levels. J. Clin. Endocrinol. Metab. 2012, 97, 3989-3995. [CrossRef] [PubMed]

15. LeBlanc, E.; Chou, R.; Zakher, B.; Daeges, M.; Pappas, M. Screening for Vitamin D Deficiency: Systematic Review for the U.S. Preventive Services Task Force Recommendation; Agency for Healthcare Research and Quality: Rockville, MD, USA, 2014. 
16. LeBlanc, E.S.; Zakher, B.; Daeges, M.; Pappas, M.; Chou, R. Screening for vitamin D deficiency: A systematic review for the U.S. Preventive Services Task Force. Ann. Intern. Med. 2015, 162, 109-122. [CrossRef] [PubMed]

17. Gillespie, L.D.; Robertson, M.C.; Gillespie, W.J.; Sherrington, C.; Gates, S.; Clemson, L.M.; Lamb, S.E. Interventions for preventing falls in older people living in the community. Cochrane Database Syst. Rev. 2012. [CrossRef] [PubMed]

18. Bhattoa, H.P.; Konstantynowicz, J.; Laszcz, N.; Wojcik, M.; Pludowski, P. Vitamin D: Musculoskeletal health. Rev. Endocr. Metab. Disord. 2017, 18, 363-371. [CrossRef] [PubMed]

19. Sanders, K.M.; Stuart, A.L.; Williamson, E.J.; Simpson, J.A.; Kotowicz, M.A.; Young, D.; Nicholson, G.C. Annual high-dose oral vitamin D and falls and fractures in older women: A randomized controlled trial. JAMA 2010, 303, 1815-1822. [CrossRef] [PubMed]

20. Bischoff-Ferrari, H.A.; Dawson-Hughes, B.; Orav, E.J.; Staehelin, H.B.; Meyer, O.W.; Theiler, R.; Dick, W.; Willett, W.C.; Egli, A. Monthly high-dose vitamin D Treatment for the prevention of functional decline: A randomized clinical trial. JAMA Intern. Med. 2016, 176, 175-183. [CrossRef] [PubMed]

21. Amrein, K.; Quraishi, S.A.; Litonjua, A.A.; Gibbons, F.K.; Pieber, T.R.; Camargo, C.A.; Giovannucci, E.; Christopher, K.B. Evidence for a U-shaped relationship between prehospital vitamin D status and mortality: A cohort study. J. Clin. Endocrinol. Metab. 2014, 99, 1461-1469. [CrossRef] [PubMed]

22. Airey, F.S. Vitamin D as a remedy for lupus vulgaris. Med. World 1946, 64, 807-810. [PubMed]

23. Herrera, G. Vitamin D in massive doses as an adjuvant to the sulfones in the treatment of tuberculoid leprosy. Int. J. Lepr. 1949, 17, 35-42. [PubMed]

24. Wang, T.-T.; Nestel, F.P.; Bourdeau, V.; Nagai, Y.; Wang, Q.; Liao, J.; Tavera-Mendoza, L.; Lin, R.; Hanrahan, J.W.; Mader, S.; et al. Cutting edge: 1,25-dihydroxyvitamin $\mathrm{D}_{3}$ is a direct inducer of antimicrobial peptide gene expression. J. Immunol. 2004, 173, 2909-2912. [CrossRef] [PubMed]

25. Gombart, A.F.; Borregaard, N.; Koeffler, H.P. Human cathelicidin antimicrobial peptide (CAMP) gene is a direct target of the vitamin $\mathrm{D}$ receptor and is strongly up-regulated in myeloid cells by 1,25-dihydroxyvitamin D. FASEB J. 2005, 19, 1067-1077. [CrossRef] [PubMed]

26. Dai, X.; Sayama, K.; Tohyama, M.; Shirakata, Y.; Hanakawa, Y.; Tokumaru, S.; Yang, L.; Hirakawa, S.; Hashimoto, K. PPAR $\gamma$ mediates innate immunity by regulating the $1 \alpha, 25$-dihydroxyvitamin $\mathrm{D}_{3}$ induced hBD-3 and cathelicidin in human keratinocytes. J. Dermatol. Sci. 2010, 60, 179-186. [CrossRef] [PubMed]

27. Liu, P.T.; Stenger, S.; Tang, D.H.; Modlin, R.L. Cutting edge: Vitamin D-mediated human antimicrobial activity against Mycobacterium tuberculosis is dependent on the induction of cathelicidin. J. Immunol. 2007, 179, 2060-2063. [CrossRef] [PubMed]

28. White, J.H. Vitamin D as an inducer of cathelicidin antimicrobial peptide expression: Past, present and future. J. Steroid Biochem. Mol. Biol. 2010, 121, 234-238. [CrossRef] [PubMed]

29. Bursuker, I.; Goldman, R. On the origin of macrophage heterogeneity: A hypothesis. J. Reticuloendothel. Soc. 1983, 33, 207-220. [PubMed]

30. Kim, E.W.; Teles, R.M.B.; Haile, S.; Liu, P.T.; Modlin, R.L. Vitamin D status contributes to the antimicrobial activity of macrophages against Mycobacterium leprae. PLoS Negl. Trop. Dis. 2018, 12. [CrossRef] [PubMed]

31. ÖvünçHacıhamdioğlu, D.; Altun, D.; Hacıhamdioğlu, B.; Çekmez, F.; Aydemir, G.; Kul, M.; Müftüoğlu, T.; Süleymanoğlu, S.; Karademir, F. The association between serum 25-hydroxy vitamin D level and urine cathelicidin in children with a urinary tract infection. J. Clin. Res. Pediatr. Endocrinol. 2016, 8, 325-329. [CrossRef] [PubMed]

32. Georgieva, V.; Kamolvit, W.; Herthelius, M.; Lüthje, P.; Brauner, A.; Chromek, M. Association between vitamin $\mathrm{D}$, antimicrobial peptides and urinary tract infection in infants and young children. Acta Paediatr. 2018. [CrossRef] [PubMed]

33. Persson, L.J.P.; Aanerud, M.; Hardie, J.A.; Miodini Nilsen, R.; Bakke, P.S.; Eagan, T.M.; Hiemstra, P.S. Antimicrobial peptide levels are linked to airway inflammation, bacterial colonisation and exacerbations in chronic obstructive pulmonary disease. Eur. Respir. J. 2017, 49. [CrossRef] [PubMed]

34. Ramos-Martínez, E.; López-Vancell, M.R.; Fernández de Córdova-Aguirre, J.C.; Rojas-Serrano, J.; Chavarría, A.; Velasco-Medina, A.; Velázquez-Sámano, G. Reduction of respiratory infections in asthma patients supplemented with vitamin D is related to increased serum IL-10 and IFN $\gamma$ levels and cathelicidin expression. Cytokine 2018, 108, 239-246. [CrossRef] [PubMed] 
35. Mathias, E.; Tangpricha, V.; Sarnaik, A.; Farooqi, A.; Sethuraman, U. Association of vitamin D with cathelicidin and vitamin D binding protein in pediatric sepsis. J. Clin. Transl. Endocrinol. 2017, 10, 36-38. [CrossRef] [PubMed]

36. Greulich, T.; Regner, W.; Branscheidt, M.; Herr, C.; Koczulla, A.R.; Vogelmeier, C.F.; Bals, R. Altered blood levels of vitamin D, cathelicidin and parathyroid hormone in patients with sepsis-a pilot study. Anaesth. Intensive Care 2017, 45, 36-45. [PubMed]

37. Quraishi, S.A.; De Pascale, G.; Needleman, J.S.; Nakazawa, H.; Kaneki, M.; Bajwa, E.K.; Camargo, C.A.; Bhan, I. Effect of cholecalciferol supplementation on vitamin D status and cathelicidin levels in sepsis: A randomized, placebo-controlled trial. Crit. Care Med. 2015, 43, 1928-1937. [CrossRef] [PubMed]

38. Aguilar-Jimenez, W.; Zapata, W.; Rugeles, M.T. Antiviral molecules correlate with vitamin D pathway genes and are associated with natural resistance to HIV-1 infection. Microbes. Infect. 2016, 18, 510-516. [CrossRef] [PubMed]

39. Coussens, A.K.; Naude, C.E.; Goliath, R.; Chaplin, G.; Wilkinson, R.J.; Jablonski, N.G. High-dose vitamin D3 reduces deficiency caused by low UVB exposure and limits HIV-1 replication in urban Southern Africans. PNAS 2015, 112, 8052-8057. [CrossRef] [PubMed]

40. Liu, P.T.; Schenk, M.; Walker, V.P.; Dempsey, P.W.; Kanchanapoomi, M.; Wheelwright, M.; Vazirnia, A.; Zhang, X.; Steinmeyer, A.; Zügel, U.; et al. Convergence of IL-1beta and VDR activation pathways in human TLR2/1-induced antimicrobial responses. PLOS ONE 2009, 4. [CrossRef]

41. Castañeda-Delgado, J.E.; Araujo, Z.; Gonzalez-Curiel, I.; Serrano, C.J.; Rivas Santiago, C.; Enciso-Moreno, J.A.; Rivas-Santiago, B. Vitamin D and l-isoleucine promote antimicrobial peptide hBD-2 production in peripheral blood mononuclear cells from elderly individuals. Int. J. Vitam. Nutr. Res. 2016, 86, 56-61. [CrossRef] [PubMed]

42. Sly, L.M.; Lopez, M.; Nauseef, W.M.; Reiner, N.E. 1alpha,25-Dihydroxyvitamin $\mathrm{D}_{3}$-induced monocyte antimycobacterial activity is regulated by phosphatidylinositol 3-kinase and mediated by the NADPHdependent phagocyte oxidase. J. Biol. Chem. 2001, 276, 35482-35493. [CrossRef] [PubMed]

43. Shin, D.-M.; Yuk, J.-M.; Lee, H.-M.; Lee, S.-H.; Son, J.W.; Harding, C.V.; Kim, J.-M.; Modlin, R.L.; Jo, E.-K. Mycobacterial lipoprotein activates autophagy via TLR2/1/CD14 and a functional vitamin D receptor signaling. Cell. Microbiol. 2010, 12, 1648-1665. [CrossRef] [PubMed]

44. Yin, Z.; Pintea, V.; Lin, Y.; Hammock, B.D.; Watsky, M.A. Vitamin D enhances corneal epithelial barrier function. Invest. Ophthalmol. Vis. Sci. 2011, 52, 7359-7364. [CrossRef] [PubMed]

45. Pálmer, H.G.; González-Sancho, J.M.; Espada, J.; Berciano, M.T.; Puig, I.; Baulida, J.; Quintanilla, M.; Cano, A.; de Herreros, A.G.; Lafarga, M.; et al. Vitamin $\mathrm{D}_{3}$ promotes the differentiation of colon carcinoma cells by the induction of E-cadherin and the inhibition of beta-catenin signaling. J. Cell Biol. 2001, 154, 369-387. [CrossRef] [PubMed]

46. D'Amelio, P.; Sassi, F. Gut Microbiota, Immune System, and Bone. Calcif. Tissue Int. 2018, 102, $415-425$. [CrossRef] [PubMed]

47. Caricilli, A.M.; Picardi, P.K.; de Abreu, L.L.; Ueno, M.; Prada, P.O.; Ropelle, E.R.; Hirabara, S.M.; Castoldi, Â.; Vieira, P.; Camara, N.O.S.; et al. Gut microbiota is a key modulator of insulin resistance in TLR 2 knockout mice. PLoS Biol. 2011, 9. [CrossRef] [PubMed]

48. Flanagan, P.K.; Chiewchengchol, D.; Wright, H.L.; Edwards, S.W.; Alswied, A.; Satsangi, J.; Subramanian, S.; Rhodes, J.M.; Campbell, B.J. Killing of escherichia coli by Crohn's disease monocyte-derived macrophages and its enhancement by hydroxychloroquine and vitamin D. Inflamm. Bowel Dis. 2015, 21, 1499-1510. [CrossRef] [PubMed]

49. Su, D.; Nie, Y.; Zhu, A.; Chen, Z.; Wu, P.; Zhang, L.; Luo, M.; Sun, Q.; Cai, L.; Lai, Y.; et al. Vitamin D signaling through induction of paneth cell defensins maintains gut microbiota and improves metabolic disorders and hepatic steatosis in animal models. Front Physiol. 2016, 7. [CrossRef] [PubMed]

50. Wu, S.; Liao, A.P.; Xia, Y.; Li, Y.C.; Li, J.-D.; Sartor, R.B.; Sun, J. Vitamin D receptor negatively regulates bacterial-stimulated NF-kappaB activity in intestine. Am. J. Pathol. 2010, 177, 686-697. [CrossRef] [PubMed]

51. Liu, W.; Chen, Y.; Golan, M.A.; Annunziata, M.L.; Du, J.; Dougherty, U.; Kong, J.; Musch, M.; Huang, Y.; Pekow, J.; et al. Intestinal epithelial vitamin D receptor signaling inhibits experimental colitis. JCI 2013, 123, 3983-3996. [CrossRef] [PubMed] 
52. Golan, M.A.; Liu, W.; Shi, Y.; Chen, L.; Wang, J.; Liu, T.; Li, Y.C. Transgenic expression of vitamin D receptor in gut epithelial cells ameliorates spontaneous colitis caused by interleukin-10 deficiency. Dig. Dis. Sci. 2015, 60, 1941-1947. [CrossRef] [PubMed]

53. Du, J.; Chen, Y.; Shi, Y.; Liu, T.; Cao, Y.; Tang, Y.; Ge, X.; Nie, H.; Zheng, C.; Li, Y.C. 1,25-Dihydroxyvitamin $\mathrm{D}$ protects intestinal epithelial barrier by regulating the myosin light chain kinase signaling pathway. Inflamm. Bowel Dis. 2015, 21, 2495-2506. [CrossRef] [PubMed]

54. He, L.; Liu, T.; Shi, Y.; Tian, F.; Hu, H.; Deb, D.K.; Chen, Y.; Bissonnette, M.; Li, Y.C. Gut epithelial vitamin $\mathrm{D}$ receptor regulates microbiota-dependent mucosal inflammation by suppressing intestinal epithelial cell apoptosis. Endocrinology 2018, 159, 967-979. [CrossRef] [PubMed]

55. Loftus, E.V.; Sandborn, W.J. Epidemiology of inflammatory bowel disease. Gastroenterol. Clin. North Am. 2002, 31, 1-20. [CrossRef]

56. Loftus, E.V. Clinical epidemiology of inflammatory bowel disease: Incidence, prevalence, and environmental influences. Gastroenterology 2004, 126, 1504-1517. [CrossRef] [PubMed]

57. Lim, W.-C.; Hanauer, S.B.; Li, Y.C. Mechanisms of disease: Vitamin D and inflammatory bowel disease. Nat. Clin. Pract. Gastroenterol. Hepatol. 2005, 2, 308-315. [CrossRef] [PubMed]

58. Ananthakrishnan, A.N.; Cagan, A.; Gainer, V.S.; Cheng, S.-C.; Cai, T.; Szolovits, P.; Shaw, S.Y.; Churchill, S.; Karlson, E.W.; Murphy, S.N.; et al. Higher plasma vitamin D is associated with reduced risk of Clostridium difficile infection in patients with inflammatory bowel diseases. Aliment. Pharmacol. Ther. 2014, 39, 1136-1142. [CrossRef] [PubMed]

59. Schäffler, H.; Herlemann, D.P.; Klinitzke, P.; Berlin, P.; Kreikemeyer, B.; Jaster, R.; Lamprecht, G. Vitamin D administration leads to a shift of the intestinal bacterial composition in Crohn's disease patients, but not in healthy controls. J. Dig. Dis. 2018, 19, 225-234. [CrossRef] [PubMed]

60. Garg, M.; Hendy, P.; Ding, J.N.; Shaw, S.; Hold, G.; Hart, A. The effect of vitamin D on intestinal inflammation and faecal microbiota in patients with ulcerative colitis. J. Crohns. Colitis. 2018, 12, 963-972. [CrossRef] [PubMed]

61. Luthold, R.V.; Fernandes, G.R.; Franco-de-Moraes, A.C.; Folchetti, L.G.D.; Ferreira, S.R.G. Gut microbiota interactions with the immunomodulatory role of vitamin D in normal individuals. Metab. Clin. Exp. 2017, 69, 76-86. [CrossRef] [PubMed]

62. Bashir, M.; Prietl, B.; Tauschmann, M.; Mautner, S.I.; Kump, P.K.; Treiber, G.; Wurm, P.; Gorkiewicz, G.; Högenauer, C.; Pieber, T.R. Effects of high doses of vitamin $\mathrm{D}_{3}$ on mucosa-associated gut microbiome vary between regions of the human gastrointestinal tract. Eur. J. Nutr. 2016, 55, 1479-1489. [CrossRef] [PubMed]

63. Kanhere, M.; He, J.; Chassaing, B.; Ziegler, T.R.; Alvarez, J.A.; Ivie, E.A.; Hao, L.; Hanfelt, J.; Gewirtz, A.T.; Tangpricha, V. Bolus weekly vitamin $\mathrm{D}_{3}$ supplementation impacts gut and airway microbiota in adults with cystic fibrosis: A double-blind, randomized, placebo-controlled clinical trial. J. Clin. Endocrinol. Metab. 2018, 103, 564-574. [CrossRef] [PubMed]

64. Bora, S.A.; Kennett, M.J.; Smith, P.B.; Patterson, A.D.; Cantorna, M.T. The gut microbiota regulates endocrine vitamin D metabolism through fibroblast growth factor 23. Front Immunol. 2018, 9. [CrossRef] [PubMed]

65. Chun, R.F.; Liu, P.T.; Modlin, R.L.; Adams, J.S.; Hewison, M. Impact of vitamin D on immune function: Lessons learned from genome-wide analysis. Front Physiol. 2014, 5. [CrossRef] [PubMed]

66. Carvalho, J.T.G.; Schneider, M.; Cuppari, L.; Grabulosa, C.C.; T Aoike, D.Q.; Redublo, B.M.C.; Batista, M.; Cendoroglo, M.; Maria Moyses, R.; Dalboni, M.A. Cholecalciferol decreases inflammation and improves vitamin D regulatory enzymes in lymphocytes in the uremic environment: A randomized controlled pilot trial. PLoS ONE 2017, 12. [CrossRef] [PubMed]

67. Xie, Z.; Chen, J.; Zheng, C.; Wu, J.; Cheng, Y.; Zhu, S.; Lin, C.; Cao, Q.; Zhu, J.; Jin, T. 1,25-dihydroxyvitamin $\mathrm{D}_{3}$-induced dendritic cells suppress experimental autoimmune encephalomyelitis by increasing proportions of the regulatory lymphocytes and reducing T helper type 1 and type 17 cells. Immunology 2017, 152, 414-424. [CrossRef] [PubMed]

68. Zhou, S.-H.; Wang, X.; Fan, M.-Y.; Li, H.-L.; Bian, F.; Huang, T.; Fang, H.-Y. Influence of vitamin D deficiency on T cell subsets and related indices during spinal tuberculosis. Exp. Ther. Med. 2018, 16, 718-722. [CrossRef] [PubMed]

69. Stubbs, J.R.; Idiculla, A.; Slusser, J.; Menard, R.; Quarles, L.D. Cholecalciferol supplementation alters calcitriol-responsive monocyte proteins and decreases inflammatory cytokines in ESRD. J. Am. Soc. Nephrol. 2010, 21, 353-361. [CrossRef] [PubMed] 
70. Drozdenko, G.; Heine, G.; Worm, M. Oral vitamin D increases the frequencies of CD38+ human B cells and ameliorates IL-17-producing T cells. Exp. Dermatol. 2014, 23, 107-112. [CrossRef] [PubMed]

71. Bendix-Struve, M.; Bartels, L.E.; Agnholt, J.; Dige, A.; Jørgensen, S.P.; Dahlerup, J.F. Vitamin $D_{3}$ treatment of Crohn's disease patients increases stimulated T cell IL-6 production and proliferation. Aliment. Pharmacol. Ther. 2010, 32, 1364-1372. [CrossRef] [PubMed]

72. Seibert, E.; Heine, G.H.; Ulrich, C.; Seiler, S.; Köhler, H.; Girndt, M. Influence of cholecalciferol supplementation in hemodialysis patients on monocyte subsets: A randomized, double-blind, placebo-controlled clinical trial. Nephron. Clin. Pract. 2013, 123, 209-219. [CrossRef] [PubMed]

73. Buondonno, I.; Rovera, G.; Sassi, F.; Rigoni, M.M.; Lomater, C.; Parisi, S.; Pellerito, R.; Isaia, G.C.; D'Amelio, P. Vitamin D and immunomodulation in early rheumatoid arthritis: A randomized double-blind placebo-controlled study. PLoS ONE 2017, 12. [CrossRef] [PubMed]

74. Boonstra, A.; Barrat, F.J.; Crain, C.; Heath, V.L.; Savelkoul, H.F.; O'Garra, A. 1alpha,25-Dihydroxyvitamin $\mathrm{D}_{3}$ has a direct effect on naive CD4+ T cells to enhance the development of Th2 cells. J. Immunol. 2001, 167, 4974-4980. [CrossRef] [PubMed]

75. Pichler, J.; Gerstmayr, M.; Szépfalusi, Z.; Urbanek, R.; Peterlik, M.; Willheim, M. 1 alpha,25(OH) ${ }_{2} \mathrm{D}_{3}$ inhibits not only Th1 but also Th2 differentiation in human cord blood T cells. Pediatr. Res. 2002, 52, 12-18. [PubMed]

76. Staeva-Vieira, T.P.; Freedman, L.P. 1,25-dihydroxyvitamin D3 inhibits IFN-gamma and IL-4 levels during in vitro polarization of primary murine CD4+ T cells. J. Immunol. 2002, 168, 1181-1189. [CrossRef] [PubMed]

77. Fawaz, L.; Mrad, M.F.; Kazan, J.M.; Sayegh, S.; Akika, R.; Khoury, S.J. Comparative effect of 25(OH)D 3 and 1,25(OH $)_{2} \mathrm{D}_{3}$ on Th17 cell differentiation. Clin. Immunol. 2016, 166, 59-71. [CrossRef] [PubMed]

78. Şılklar, Z.; Karataş, D.; Doğu, F.; Hacıhamdioğlu, B.; İkincioğulları, A.; Berberoğlu, M. Regulatory T cells and vitamin D status in children with chronic autoimmune thyroiditis. J. Clin. Res. Pediatr. Endocrinol. 2016, 8, 276-281. [CrossRef] [PubMed]

79. Korf, H.; Wenes, M.; Stijlemans, B.; Takiishi, T.; Robert, S.; Miani, M.; Eizirik, D.L.; Gysemans, C.; Mathieu, C. 1,25-Dihydroxyvitamin $\mathrm{D}_{3}$ curtails the inflammatory and $\mathrm{T}$ cell stimulatory capacity of macrophages through an IL-10-dependent mechanism. Immunobiology 2012, 217, 1292-1300. [CrossRef] [PubMed]

80. Mann, E.H.; Ho, T.-R.; Pfeffer, P.E.; Matthews, N.C.; Chevretton, E.; Mudway, I.; Kelly, F.J.; Hawrylowicz, C.M. Vitamin D counteracts an IL-23-dependent IL-17A+IFN- $\gamma+$ response driven by urban particulate matter. Am. J. Respir. Cell Mol. Biol. 2017, 57, 355-366. [CrossRef] [PubMed]

81. Joshi, S.; Pantalena, L.-C.; Liu, X.K.; Gaffen, S.L.; Liu, H.; Rohowsky-Kochan, C.; Ichiyama, K.; Yoshimura, A.; Steinman, L.; Christakos, S.; et al. 1,25-dihydroxyvitamin $\mathrm{D}_{3}$ ameliorates Th17 autoimmunity via transcriptional modulation of interleukin-17A. Mol. Cell. Biol. 2011, 31, 3653-3669. [CrossRef] [PubMed]

82. Chang, J.-H.; Cha, H.-R.; Lee, D.-S.; Seo, K.Y.; Kweon, M.-N. 1,25-Dihydroxyvitamin $D_{3}$ inhibits the differentiation and migration of TH17 cells to protect against experimental autoimmune encephalomyelitis. PLOS ONE 2010, 5. [CrossRef]

83. Colin, E.M.; Asmawidjaja, P.S.; van Hamburg, J.P.; Mus, A.M.C.; van Driel, M.; Hazes, J.M.W.; van Leeuwen, J.P.T.M.; Lubberts, E. 1,25-dihydroxyvitamin $\mathrm{D}_{3}$ modulates Th17 polarization and interleukin-22 expression by memory $\mathrm{T}$ cells from patients with early rheumatoid arthritis. Arthritis Rheum. 2010, 62, 132-142. [CrossRef] [PubMed]

84. Palmer, M.T.; Lee, Y.K.; Maynard, C.L.; Oliver, J.R.; Bikle, D.D.; Jetten, A.M.; Weaver, C.T. Lineage-specific effects of 1,25-dihydroxyvitamin $\mathrm{D}_{3}$ on the development of effector CD4 T cells. J. Biol. Chem. 2011, 286, 997-1004. [CrossRef] [PubMed]

85. Treiber, G.; Prietl, B.; Fröhlich-Reiterer, E.; Lechner, E.; Ribitsch, A.; Fritsch, M.; Rami-Merhar, B.; Steigleder-Schweiger, C.; Graninger, W.; Borkenstein, M.; et al. Cholecalciferol supplementation improves suppressive capacity of regulatory T-cells in young patients with new-onset type 1 diabetes mellitus-A randomized clinical trial. Clin. Immunol. 2015, 161, 217-224. [CrossRef] [PubMed]

86. Hu, J.; Wan, Y. Tolerogenic dendritic cells and their potential applications. Immunology 2011, 132, 307-314. [CrossRef] [PubMed]

87. Penna, G.; Adorini, L. 1 Alpha,25-dihydroxyvitamin $\mathrm{D}_{3}$ inhibits differentiation, maturation, activation, and survival of dendritic cells leading to impaired alloreactive T cell activation. J. Immunol. 2000, 164, 2405-2411. [CrossRef] [PubMed] 
88. Piemonti, L.; Monti, P.; Sironi, M.; Fraticelli, P.; Leone, B.E.; Dal Cin, E.; Allavena, P.; Di Carlo, V. Vitamin $\mathrm{D}_{3}$ affects differentiation, maturation, and function of human monocyte-derived dendritic cells. J. Immunol. 2000, 164, 4443-4451. [CrossRef] [PubMed]

89. Unger, W.W.J.; Laban, S.; Kleijwegt, F.S.; van der Slik, A.R.; Roep, B.O. Induction of Treg by monocyte-derived DC modulated by vitamin $\mathrm{D}_{3}$ or dexamethasone: Differential role for PD-L1. Eur. J. Immunol. 2009, 39, 3147-3159. [CrossRef] [PubMed]

90. Van Halteren, A.G.S.; Tysma, O.M.; van Etten, E.; Mathieu, C.; Roep, B.O. 1alpha,25-dihydroxyvitamin D3 or analogue treated dendritic cells modulate human autoreactive $\mathrm{T}$ cells via the selective induction of apoptosis. J. Autoimmun. 2004, 23, 233-239. [CrossRef] [PubMed]

91. Lemire, J.M.; Archer, D.C. 1,25-dihydroxyvitamin $\mathrm{D}_{3}$ prevents the in vivo induction of murine experimental autoimmune encephalomyelitis. JCI 1991, 87, 1103-1107. [CrossRef] [PubMed]

92. Cantorna, M.T.; Hayes, C.E.; DeLuca, H.F. 1,25-Dihydroxyvitamin $\mathrm{D}_{3}$ reversibly blocks the progression of relapsing encephalomyelitis, a model of multiple sclerosis. PNAS 1996, 93, 7861-7864. [CrossRef] [PubMed]

93. Cantorna, M.T.; Hayes, C.E.; DeLuca, H.F. 1,25-Dihydroxycholecalciferol inhibits the progression of arthritis in murine models of human arthritis. J. Nutr. 1998, 128, 68-72. [CrossRef] [PubMed]

94. Alhassan Mohammed, H.; Mirshafiey, A.; Vahedi, H.; Hemmasi, G.; Moussavi NaslKhameneh, A.; Parastouei, K.; Saboor-Yaraghi, A.A. Immunoregulation of inflammatory and inhibitory cytokines by vitamin $\mathrm{D}_{3}$ in patients with inflammatory bowel diseases. Scand. J. Immunol. 2017, 85, 386-394. [CrossRef] [PubMed]

95. Tao, C.; Simpson, S.; van der Mei, I.; Blizzard, L.; Havrdova, E.; Horakova, D.; Shaygannejad, V.; Lugaresi, A.; Izquierdo, G.; Trojano, M.; et al. Higher latitude is significantly associated with an earlier age of disease onset in multiple sclerosis. J. Neurol. Neurosurg. Psychiatry 2016, 87, 1343-1349. [CrossRef] [PubMed]

96. Laursen, J.H.; Søndergaard, H.B.; Sørensen, P.S.; Sellebjerg, F.; Oturai, A.B. Vitamin D supplementation reduces relapse rate in relapsing-remitting multiple sclerosis patients treated with natalizumab. Mult. Scler. Relat. Disord. 2016, 10, 169-173. [CrossRef] [PubMed]

97. Jelinek, G.A.; Marck, C.H.; Weiland, T.J.; Pereira, N.; van der Meer, D.M.; Hadgkiss, E.J. Latitude, sun exposure and vitamin D supplementation: Associations with quality of life and disease outcomes in a large international cohort of people with multiple sclerosis. BMC Neurol. 2015, 15. [CrossRef] [PubMed]

98. Mohr, S.B.; Garland, C.F.; Gorham, E.D.; Garland, F.C. The association between ultraviolet B irradiance, vitamin D status and incidence rates of type 1 diabetes in 51 regions worldwide. Diabetologia 2008, 51, 1391-1398. [CrossRef] [PubMed]

99. Rosecrans, R.; Dohnal, J.C. Seasonal vitamin D changes and the impact on health risk assessment. Clin. Biochem. 2014, 47, 670-672. [CrossRef] [PubMed]

100. Van der Rhee, H.J.; de Vries, E.; Coebergh, J.W. Regular sun exposure benefits health. Med. Hypotheses 2016, 97, 34-37. [CrossRef] [PubMed]

101. Szilagyi, A.; Leighton, H.; Burstein, B.; Xue, X. Latitude, sunshine, and human lactase phenotype distributions may contribute to geographic patterns of modern disease: The inflammatory bowel disease model. Clin. Epidemiol. 2014, 6, 183-198. [CrossRef] [PubMed]

102. Dobson, R.; Giovannoni, G.; Ramagopalan, S. The month of birth effect in multiple sclerosis: Systematic review, meta-analysis and effect of latitude. J. Neurol. Neurosurg. Psychiatry 2013, 84, 427-432. [CrossRef] [PubMed]

103. Song, G.G.; Bae, S.-C.; Lee, Y.H. Association between vitamin D intake and the risk of rheumatoid arthritis: A meta-analysis. Clin. Rheumatol. 2012, 31, 1733-1739. [CrossRef] [PubMed]

104. Zipitis, C.S.; Akobeng, A.K. Vitamin D supplementation in early childhood and risk of type 1 diabetes: A systematic review and meta-analysis. Arch. Dis. Child. 2008, 93, 512-517. [CrossRef] [PubMed]

105. Dong, J.-Y.; Zhang, W.-G.; Chen, J.J.; Zhang, Z.-L.; Han, S.-F.; Qin, L.-Q. Vitamin D intake and risk of type 1 diabetes: A meta-analysis of observational studies. Nutrients 2013, 5, 3551-3562. [CrossRef] [PubMed]

106. Shen, L.; Zhuang, Q.-S.; Ji, H.-F. Assessment of vitamin D levels in type 1 and type 2 diabetes patients: Results from metaanalysis. Mol. Nutr. Food Res. 2016, 60, 1059-1067. [CrossRef] [PubMed]

107. Duan, S.; Lv, Z.; Fan, X.; Wang, L.; Han, F.; Wang, H.; Bi, S. Vitamin D status and the risk of multiple sclerosis: A systematic review and meta-analysis. Neurosci. Lett. 2014, 570, 108-113. [CrossRef] [PubMed]

108. Lin, J.; Liu, J.; Davies, M.L.; Chen, W. Serum vitamin D Level and rheumatoid arthritis disease activity: Review and meta-analysis. PLoS ONE 2016, 11. [CrossRef] [PubMed] 
109. Del Pinto, R.; Pietropaoli, D.; Chandar, A.K.; Ferri, C.; Cominelli, F. Association between inflammatory bowel disease and vitamin D deficiency: A systematic review and meta-analysis. Inflamm. Bowel Dis. 2015, 21, 2708-2717. [CrossRef] [PubMed]

110. Lu, C.; Yang, J.; Yu, W.; Li, D.; Xiang, Z.; Lin, Y.; Yu, C. Association between 25(OH)D level, ultraviolet exposure, geographical location, and inflammatory bowel disease activity: A systematic review and meta-analysis. PLoS ONE 2015, 10. [CrossRef] [PubMed]

111. Sadeghian, M.; Saneei, P.; Siassi, F.; Esmaillzadeh, A. Vitamin D status in relation to Crohn's disease: Meta-analysis of observational studies. Nutrition 2016, 32, 505-514. [CrossRef] [PubMed]

112. Feng, R.; Li, Y.; Li, G.; Li, Z.; Zhang, Y.; Li, Q.; Sun, C. Lower serum $25(\mathrm{OH})$ D concentrations in type 1 diabetes: A meta-analysis. Diabetes Res. Clin. Pract. 2015, 108, e71-e75. [CrossRef] [PubMed]

113. Pitocco, D.; Crinò, A.; Di Stasio, E.; Manfrini, S.; Guglielmi, C.; Spera, S.; Anguissola, G.B.; Visalli, N.; Suraci, C.; Matteoli, M.C.; et al. The effects of calcitriol and nicotinamide on residual pancreatic beta-cell function in patients with recent-onset Type 1 diabetes (IMDIAB XI). Diabet. Med. 2006, 23, 920-923. [CrossRef] [PubMed]

114. Walter, M.; Kaupper, T.; Adler, K.; Foersch, J.; Bonifacio, E.; Ziegler, A.-G. No effect of the 1alpha,25dihydroxyvitamin $\mathrm{D}_{3}$ on beta-cell residual function and insulin requirement in adults with new-onset type 1 diabetes. Diabetes Care 2010, 33, 1443-1448. [CrossRef] [PubMed]

115. Papadimitriou, D.T.; Marakaki, C.; Fretzayas, A.; Nicolaidou, P.; Papadimitriou, A. Negativation of type 1 diabetes-associated autoantibodies to glutamic acid decarboxylase and insulin in children treated with oral calcitriol. J. Diabetes 2013, 5, 344-348. [CrossRef] [PubMed]

116. Gunasekar, P.; Swier, V.J.; Fleegel, J.P.; Boosani, C.S.; Radwan, M.M.; Agrawal, D.K. Vitamin D and macrophage polarization in epicardial adipose tissue of atherosclerotic swine. PLoS ONE 2018, 13. [CrossRef] [PubMed]

117. Yin, K.; You, Y.; Swier, V.; Tang, L.; Radwan, M.M.; Pandya, A.N.; Agrawal, D.K. Vitamin D protects against atherosclerosis via regulation of cholesterol efflux and macrophage polarization in hypercholesterolemic swine. Arterioscler. Thromb. Vasc. Biol. 2015, 35, 2432-2442. [CrossRef] [PubMed]

118. Dozio, E.; Briganti, S.; Vianello, E.; Dogliotti, G.; Barassi, A.; Malavazos, A.E.; Ermetici, F.; Morricone, L.; Sigruener, A.; Schmitz, G.; et al. Epicardial adipose tissue inflammation is related to vitamin D deficiency in patients affected by coronary artery disease. Nutr. Metab. Cardiovasc. Dis. 2015, 25, 267-273. [CrossRef] [PubMed]

119. Apostolakis, M.; Armeni, E.; Bakas, P.; Lambrinoudaki, I. Vitamin D and cardiovascular disease. Maturitas 2018, 115, 1-22. [CrossRef] [PubMed]

(C) 2018 by the authors. Licensee MDPI, Basel, Switzerland. This article is an open access article distributed under the terms and conditions of the Creative Commons Attribution (CC BY) license (http://creativecommons.org/licenses/by/4.0/). 